\title{
Knowledge, Attitude and Practice among endodontists of Nepal in patient management during COVID-19 arena
}

\author{
Deepa Kunwar*1, Snigdha Subham², Manisha Nepal'², Jwolan Khadka
}

'Department of Conservative Dentistry and Endodontics, Gandaki Medical College, ${ }^{2}$ Department of Conservative Dentistry and Endodontics, Universal College of Medical Science, ${ }^{3}$ Department of Conservative Dentistry and Endodontics, KIST Medical College

\begin{abstract}
Introduction: Coronavirus disease, 2019 is an infectious disease caused by the severe acute respiratory syndrome coronavirus 2. COVID-19 is a global pandemic affecting all aspects of life in most countries. Endodontists are at inherent risk because of aerosol generation during dental procedures. The objective of the study was to assess the knowledge, attitude and practice among endodontists of Nepal required to combat the COVID-19 pandemic. Methods: A web-based cross-sectional study was conducted among endodontists of Nepal from March to June 2021. Convenient sampling method was adopted. The data were analysed using Statistical Package for the Social Sciences version 20.0. Descriptive statistics was performed, percentage and frequency distribution were assessed. Chi-square tests were used to see the association between the categorical variables. A p-value of $<0.05$ was considered statistically significant. Results: Of the 81 endodontists who responded to our study (response rate of 83\%), knowledge about the clinical features of corona virus infection was known by majority $(n=80,98 \%)$ of the responders. Majority of responders categorized the cases $(n=71,87.7 \%)$, most of the responders discussed about COVID-19 with the patients ( $n=79,97.5 \%)$. Regarding practice, almost half $(n=44,54.3 \%)$ of the responders used rubber dam during the endodontic procedures, while few $(n=14,17.3 \%)$ of the responders did not use them at all. Conclusions: Endodontists of Nepal were found to have good knowledge, attitude and practice score, for patient management during COVID-19 pandemic. Certain pitfalls in attitude and practice level can be decreased by efficient training programs, precise guidelines, and treatment protocols.
\end{abstract}

Keywords: Coronavirus, COVID-19, Endodontists, Pandemic.

\section{*Correspondence:}

Dr. Deepa Kunwar

Lecturer, Department of Conservative Dentistry and Endodontics,

Gandaki Medical College Teaching Hospital, Pokhara, Nepal

Email: drkunwardeepa@gmail.com

Submitted: October 26, 2021

Accepted: December 14, 2021

To cite: Kunwar D, Shubham S, Nepal M, Khadka J. Knowledge, Attitude and Practice among endodontists of Nepal in patient management during COVID-19 arena. JGMC Nepal. 2021;14(2):111-7.

DOI: $10.3126 /$ jgmcn.v14i2.38704

\section{INTRODUCTION}

Coronavirus disease (COVID-19) is an infectious disease caused by the severe acute respiratory syndrome coronavirus 2 (SARSCoV-2). ${ }^{1-2}$ World Health Organization (WHO) declared this outbreak as a Public Health Emergency of International concern on 30 January $2020 .^{3}$ The SARS-CoV-2 is a contagious virus and spreads from human to human primarily through respiratory droplets and potentially aerosol transmission., ${ }^{4,5}$ The symptoms of COVID-19 infection include fever, sore throat, cough, myalgia, fatigue and chest pain. In severe cases, it can lead to pneumonia, respiratory failure, cardiac arrest and death. ${ }^{6}$ Health care workers including dentists are amongst the most vulnerable groups who are at the greatest risk of getting infected especially from the micro-droplets and aerosol-generating procedures. $^{7}$ Presence of virus in saliva (91.7\% of patients) makes the dentists extremely vulnerable to contract the disease. ${ }^{8}$ In Nepal, Ministry of Health and Population (MOHP) confirmed the first case of COVID-19 officially on 23 January $2020 .{ }^{9}$ Guidelines and standard 
operating procedures, which encompass the work space as well as the principles guiding their practices, must be well formulated and strictly followed by dentist to protect themselves, staff and the patients they serve. ${ }^{10-12}$ The recommendations include use of personal protective equipment, hand washing, detailed patient evaluation, rubber dam isolation, anti-retraction handpiece, mouth rinsing before dental procedures, and disinfection of the clinic. $^{13}$

In a study by Arora et al. $^{14}$ in June 2020 in India, respondents had a fair level (40-70\%) of knowledge, which was significantly more among female respondents and those with post-graduation studies. This percentage about level of knowledge is less when compared to the study conducted by Kamate et al. ${ }^{7}$ which may be due to the fact that his study was a multinational study. Most of the previous studies had data collection on social media only so it could have resulted in the exclusion of the practitioners who were not using social media. Some states or regions across the country were more affected than others which may influence the administration and healthcare preventive measures implemented by a particular region that could also influence the result of a study.

We conducted a web-based survey using social media and email was done among consultant endodontists of Nepal to assess their existing awareness about the corona virus, mode of spread of the virus, the pandemic related to the virus, safety measures during practice of dental procedures. The objective of the study was to assess the knowledge, attitude, and practice (KAP) among endodontists of Nepal to combat the COVID-19 pandemic.

\section{METHODS}

A cross-sectional study was conducted from March to June 2021 using a web-based survey. The endodontists from all over Nepal were invited to participate in the study. Anonymity was maintained, the purpose of the study was explained to them in detail and the questionnaire was filled with their consent. No incentives were provided to the respondents. The ethical approval for this survey was obtained from the Institutional Review Committee of National Health Care Research Council, Nepal (Ref. no. IIDC/IRC/ 2095).The KAP questionnaire was formed and validated through intra class correlation after scrutinizing literature pertinent to COVID-19, SARS, dentistry and international guidelines and was in English language. ${ }^{15,16}$ The semi structured questionnaire was designed and implemented using web-based survey platform with security features (Survey Monkey 2020, California).
There were total 35 questions and the questionnaire comprised of demographic details in the first section: age, sex, years of experience, nature of work (institution or private or both), and province of current practice. The second section included total 30 questions about knowledge, attitude and practice, of which knowledge part had 7 questions, 5 questions ascertained for attitude and 18 questions ascertained for practice of the endodontists regarding COVID-19.

Total knowledge/ awareness score was calculated on the basis of each subject's response. Each positive response was awarded a score of ' 1 ' and negative response as ' 0 '. The scores on knowledge on COVID-19 ranged from 1 to 7.

The link was circulated on social media accounts like, WhatsApp, Facebook, Twitter, and E-mails to reach the target population. A universal sampling method was used to collect the data using an online method.

Data were analyzed using Statistical Package for the Social Sciences version 20.0. Categorical variables were expressed as frequencies and percentages and continuous variables as means (standard deviations). Cross-tabulation was used to examine the independence among related categorical variables. Chi- square and Fisher exact test was applied to see association between categorical variables. Statistical significance was set at $\mathrm{P}<0.05$.

\section{RESULTS}

Table1: Sociodemographic characteristic of participating endodontists

\begin{tabular}{llc}
\hline \multirow{2}{*}{ Gender } & Characteristics & Number (\%) \\
& Female & $36(44.4)$ \\
Currently practicing as & An academician & $45(55.6)$ \\
& A clinician & $22(27.2)$ \\
& Both & $10(12.3)$ \\
Years of practice & $1-5$ years & $49(60.5)$ \\
& 6-10 years & $37(45.7)$ \\
& $11-15$ years & $25(30.9)$ \\
& $>15$ years & $14(17.3)$ \\
& Province 1 & $5(6.2)$ \\
& Province 2 & $9(11.1)$ \\
& Province 3 (Bagmati) & $4(4.9)$ \\
& Province 4 (Gandaki) & $52(64.2)$ \\
Address & Province 5 (Lumbini) & $6(6.2)$ \\
& Province 6 (Karnali) & $4(4.9)$ \\
& Province 7 & $1(1.2)$ \\
\hline
\end{tabular}

Survey result on knowledge regarding COVID-19 among participants was as in table 2 . 
Total of 81 endodontists from Nepal participated in the study, majority of them were females $(n=45,55.6 \%)$. Most of the endodontists $(n=52,64.2 \%)$ were from Bagmati province. Majority of them were practicing both as an academician and clinician $(n=49,60.5 \%)$ and were in early years of career with experience period of less than five years $(n=37,45.7 \%)$. Details about the demographic characteristics of the participants are given in Table 1.

Table 2: Knowledge about COVID-19 among participants $(\mathrm{N}=81)$

\begin{tabular}{|c|c|c|}
\hline $\begin{array}{l}\text { Questions for assessment of Knowledge about } \\
\text { COVID-19 }\end{array}$ & Number & Percentage \\
\hline \multicolumn{3}{|l|}{$\begin{array}{l}\text { 1. Main clinical symptoms of COVID-19 are fever, } \\
\text { cough, shortness of breath and fatigue? }\end{array}$} \\
\hline a. Yes & 80 & 98.8 \\
\hline b. No & 1 & 1.2 \\
\hline \multicolumn{3}{|l|}{$\begin{array}{l}\text { 2. Unlike the common cold, stuffy nose, runny } \\
\text { nose and sneezing are less common in COVID-19? }\end{array}$} \\
\hline a. Yes & 71 & 87.1 \\
\hline b. No & 9 & 11.1 \\
\hline c. Don't know & 1 & 1.2 \\
\hline $\begin{array}{l}\text { 3. The symptoms of COVID-19 appear in } 2-14 \\
\text { days? }\end{array}$ & 76 & 93.8 \\
\hline a. Yes & 2 & 2.5 \\
\hline b. No & 3 & 3.7 \\
\hline \multicolumn{3}{|l|}{ c. Don't know } \\
\hline \multicolumn{3}{|l|}{$\begin{array}{l}\text { 4. Can COVID- } 19 \text { be transmitted through dental } \\
\text { treatment? }\end{array}$} \\
\hline a. Yes & 74 & 91.4 \\
\hline b. No & 3 & 3.7 \\
\hline c. Don't know & 4 & 4.9 \\
\hline \multicolumn{3}{|l|}{$\begin{array}{l}\text { 5. Under which category do endodontists fall in } \\
\text { visit of exposure? }\end{array}$} \\
\hline a. Very high & 73 & 90.1 \\
\hline b. High & 8 & 9.9 \\
\hline \multicolumn{3}{|l|}{$\begin{array}{l}\text { 6. People who have contacted with COVID-19 } \\
\text { infected person should be immediately isolated in } \\
\text { proper place? }\end{array}$} \\
\hline a. Yes & 73 & 90.1 \\
\hline b. No & 6 & 7.4 \\
\hline c. Don't know & 2 & 2.5 \\
\hline \multicolumn{3}{|l|}{ 7. Isolation and quarantine are similar thing? } \\
\hline a. Yes & 26 & 32.1 \\
\hline b. No & 48 & 59.3 \\
\hline c. Don't know & 7 & 8.6 \\
\hline
\end{tabular}

The mean total knowledge score was $6.11 \pm 0.82$ out of the maximum attainable score of seven. An analysis was performed to examine whether there were any statistically significant differences in the participants' knowledge score in terms of their demographic characteristics. Male responders had slightly higher mean score (6.14) on knowledge about COVID-19 than female responders
(6.09) but was not statistically significant ( $p=0.787)$. Statistically significant difference on participant's knowledge was noted based on the years of experience $(\mathrm{p}=<0.001)$, place of work and province of practice $(p=<0.001)$ as in table 3 . Recently graduated (below 5 years of experience) endodontists of Nepal had better knowledge about COVID-19 (mean score=6.24) than more experienced responders of the group. Responders practicing endodontics and conservative dentistry from province 2 and province 6 had less knowledge about COVID-19 than responders practicing in other provinces of Nepal (Table 3).

Table 3: Differences among participants in terms of total knowledge score

\begin{tabular}{|c|c|c|c|}
\hline Variables & Number & $\begin{array}{c}\text { Knowledge score } \\
\text { mean (standard deviation) }\end{array}$ & $P$ value \\
\hline \multicolumn{4}{|l|}{ Gender } \\
\hline Male & 36 & $6.14(0.683)$ & 0.787 \\
\hline Female & 45 & $6.09(0.925)$ & \\
\hline \multicolumn{4}{|l|}{ Years of practice } \\
\hline$<5$ years & 37 & $6.24(0.830)$ & \\
\hline 5-10 years & 25 & $5.84(0.943)$ & $0.001^{*}$ \\
\hline $10-15$ years & 14 & $6.21(0.579)$ & \\
\hline$>15$ years & 5 & $6.20(0.447)$ & \\
\hline \multicolumn{4}{|l|}{ Workplace } \\
\hline Institution & 22 & $6.05(0.785)$ & \\
\hline Clinic & 10 & $6.40(0.699)$ & $0.001^{*}$ \\
\hline Both & 49 & $6.08(0.822)$ & \\
\hline \multicolumn{4}{|l|}{ Address (Province) } \\
\hline Province 1 & 9 & $6.00(0.866)$ & \\
\hline Province 2 & 4 & $5.75(0.957)$ & $0.001^{*}$ \\
\hline Province 3 (Bagmati) & 52 & $6.21(0.750)$ & \\
\hline Province 4 (Gandaki) & 4 & $6.00(0.816)$ & \\
\hline Province 5 (Lumbini) & 5 & $6.40(0.548)$ & \\
\hline Province 6 (Karnali) & 5 & $5.20(1.304)$ & \\
\hline Province 7 & 2 & $6.50(0.707)$ & \\
\hline
\end{tabular}

\section{*Statistically significant}

At the early stages of the pandemic, the majority $(n=67$, $82.7 \%$ ) were anxious of being infected with COVID-19 from patients or co-worker. Similarly ( $n=69,85.2 \%)$ were apprehensive of providing treatment to a patient who is suspected of being infected with COVID-19 though $(n=78$, 96.3\%) had a belief that hand hygiene and PPE are effective in preventing COVID-19. Moreover, the vast majority of participants $(n=79,97.5 \%)$ were of the opinion that they do have a role to mitigate the community spread of the COVID 19 disease. (Table 4) 
Table 4: Attitude about COVID-19 among participants

\begin{tabular}{|c|c|c|}
\hline Questions for assessment of Attitude about COVID-19 & Number & Percentage \\
\hline \multirow{2}{*}{\multicolumn{3}{|c|}{$\begin{array}{l}\text { 1. Are you anxious of getting infected with COVID-19 } \\
\text { from a patient or a co-worker? }\end{array}$}} \\
\hline & & \\
\hline a. Yes & 67 & 82.7 \\
\hline b. No & 14 & 17.3 \\
\hline \multicolumn{3}{|l|}{$\begin{array}{l}\text { 2. Are you apprehensive of providing treatment to } \\
\text { a patient who is suspected of being infected with } \\
\text { COVID-19? }\end{array}$} \\
\hline a. Yes & 69 & 85.2 \\
\hline b. No & 12 & 14.8 \\
\hline \multicolumn{3}{|l|}{$\begin{array}{l}\text { 3. What procedure do you consider safe to perform } \\
\text { during COVID- } 19 \text { pandemic? }\end{array}$} \\
\hline a. All procedures & 47 & 58 \\
\hline b. Urgent / emergency treatment & 22 & 27.2 \\
\hline c. None & 12 & 14.8 \\
\hline \multicolumn{3}{|l|}{$\begin{array}{l}\text { 4. Do you think hand hygiene and PPE are effective in } \\
\text { preventing COVID-19? }\end{array}$} \\
\hline a. Yes & 78 & 96.3 \\
\hline b. No & 3 & 3.7 \\
\hline \multicolumn{3}{|l|}{$\begin{array}{l}\text { 5. Do you think we have role to mitigate the community } \\
\text { spread of this COVID-19 disease? }\end{array}$} \\
\hline a. Yes & 79 & 97.5 \\
\hline b. No & 2 & 2.5 \\
\hline
\end{tabular}

Regarding practices towards COVID-19, most of responders $(n=71,87.7 \%)$ reported that they categorize the cases on the basis of risk assessment, more than half of them ( $n=46,56.8 \%)$ do not perform routine procedures during the pandemic. Majority of the responders $(n=79$, $97.5 \%$ ) discuss about COVID-19 with the patients. Still only some of them $(n=44,54.3 \%)$ used rubber dam for the endodontic procedure. Details about the replies to the attitude and practice questions are summarized in table 4 and table 5.

Table 5: Practice about COVID-19 among participants

\begin{tabular}{lcc}
\hline Questions for assessment of Practice about COVID-19 & Number & Percentage \\
$\begin{array}{l}\text { 1. Do you perform routine case in this COVID-19 arena? } \\
\text { a. Yes }\end{array}$ & 46 & 56.8 \\
b. No & & 43.2 \\
$\begin{array}{l}\text { 2. Do you perform triaging and tele screening of patients to } \\
\text { decide the severity of case? }\end{array}$ & & \\
a. Yes & 63 & 77.8 \\
b. No & 18 & 22.2 \\
3. Do you categorize the cases on the basis risk assessment? & & \\
a. Yes & 71 & 87.7 \\
b. No & 10 & 12.3 \\
4. Do you measure the temperature of each patient and vis- & & \\
itors before entering the working place? & & \\
$\begin{array}{l}\text { a. Yes } \\
\text { b. No }\end{array}$ & 74 & 91.4 \\
5. Do you maintain social distance in your workplace? & 7 & 8.6 \\
$\begin{array}{l}\text { a. Yes } \\
\text { b. No }\end{array}$ & 75 & 92.6 \\
\end{tabular}

\begin{tabular}{|c|c|c|}
\hline \multicolumn{3}{|c|}{ 6. Do you perform procedure under PPE? } \\
\hline a. Yes & 80 & 98.8 \\
\hline b. No & 1 & 1.2 \\
\hline \multicolumn{3}{|c|}{ 7. Do you provide proper PPE, mask, eyewear to your staffs? } \\
\hline a. Yes & 78 & 96.3 \\
\hline b. No & 3 & 3.7 \\
\hline \multicolumn{3}{|c|}{$\begin{array}{l}\text { 8. Does your dental practice follow the proper disinfection } \\
\text { and sterilization protocol? }\end{array}$} \\
\hline a. Yes & 79 & 97.5 \\
\hline b. No & 2 & 2.5 \\
\hline \multicolumn{3}{|c|}{$\begin{array}{l}\text { 9. Do you think surgical mask alone enough to prevent } \\
\text { cross infection during COVID-19? }\end{array}$} \\
\hline a. Yes & 38 & 46.9 \\
\hline b. No & 43 & 53.1 \\
\hline \multicolumn{3}{|c|}{$\begin{array}{l}\text { 10. Do you know the correct method of donning and doffing } \\
\text { the PPE? }\end{array}$} \\
\hline a. Yes & 1 & 1.2 \\
\hline \multicolumn{3}{|l|}{ b. No } \\
\hline \multicolumn{3}{|c|}{$\begin{array}{l}11 \text {. Do you perform the pre-procedural mouth rinsing with } \\
1 \% \text { hydrogen peroxide or } 0.2 \% \text { povidone iodine? }\end{array}$} \\
\hline a. Yes & 74 & 91.4 \\
\hline b. No & 7 & 8.6 \\
\hline \multicolumn{3}{|c|}{ 12. Should we avoid all the procedure that produce aerosol } \\
\hline a. Strongly agree & 48 & 59.3 \\
\hline b. Agree & 14 & 17.3 \\
\hline c. Disagree & 9 & 11.1 \\
\hline d. Strongly disagree & 3 & 3.7 \\
\hline e. Undecided & 7 & 8.6 \\
\hline \multicolumn{3}{|c|}{ 13. We should minimize intraoral radiograph. } \\
\hline a. Strongly agree & 40 & 49.4 \\
\hline b. Agree & 18 & 22 \\
\hline c. Disagree & 12 & 14.8 \\
\hline d. Strongly disagree & 1 & 1.2 \\
\hline e. Undecided & 10 & 12.3 \\
\hline \multicolumn{3}{|c|}{ 14. Do you use rubber dam? } \\
\hline a. Always in all cases & 44 & 54.3 \\
\hline b. Suspected case only & 23 & 28.4 \\
\hline c. None of the cases & 14 & 17.3 \\
\hline \multicolumn{3}{|c|}{ 15. Do you have proper ventilation in your working area? } \\
\hline a. Yes & 78 & 96.3 \\
\hline b. No & 3 & 3.7 \\
\hline \multicolumn{3}{|c|}{$\begin{array}{l}\text { 16. Do you use high volume evacuation suction during pro- } \\
\text { cedure? }\end{array}$} \\
\hline a. Yes & 26 & 32.1 \\
\hline \multicolumn{3}{|l|}{ b. No } \\
\hline \multicolumn{3}{|c|}{ 17. Do you discuss the risk of COVID-19 with patient? } \\
\hline a. Yes & 79 & 97.5 \\
\hline b. No & 2 & 2.5 \\
\hline \multicolumn{3}{|c|}{$\begin{array}{l}\text { 18. Do you discuss the preventive measures against } \\
\text { CovID-19 with patients? }\end{array}$} \\
\hline a. Yes & 79 & 97.5 \\
\hline b. No & 2 & 2.5 \\
\hline
\end{tabular}

\section{DISCUSSION}

The COVID-19 pandemic has affected nearly all countries in the world impacting the majority of human activities including the economy and health care systems. ${ }^{17}$ Due to 
the fact that effective medication has not been proven and vaccines are still not available in most countries, prevention remains the only option to combat the virus. As a result, better prevention and control of COVID-19 is attained through improving the knowledge, attitude and practice of high-risk population groups toward COVID-19. ${ }^{18}$

Endodontic treatment is a specialized modality that is profoundly affected by COVID-19. It represents the majority of emergencies in dental practice. Endodontists are at greater risk to encounter the cross-infection because of employment of high-speed rotary instruments generating large volume of aerosols and splatter of saliva, during treatment. It has been reported that the coronavirus attaches to ACE-2 receptors found in the tongue, the floor of the mouth, saliva, and other oral structures. Endodontic treatment often requires multiple and longer treatment visits. ${ }^{19-20}$ The usual distance between the dentist and the working field is approx. 35 to $40 \mathrm{~cm}$, which puts the dentist at a higher risk of contracting COVID-19.21 This results in an increased and repeated exposure to the coronavirus for the dentists, their staff and patients.

According to results of the current study, responders of the study were aware about the corona virus and the COVID-19 pandemic. Nearly 94\% of the responders were aware with the clinical symptoms, mode of transmission of COVID-19 and only 59\% were aware that isolation and quarantine are different. In a study done by Khanal et al., $84.1 \%$ of the participants responded correctly regarding the mode of transmission of the corona virus. ${ }^{17}$ Similar studies done previously showed $62 \%$ and $79.2 \%$ of the health care workers from India and Pakistan respectively correctly responded regarding the mode of transmission of coronavius..$^{22,23}$

Around $85 \%$ of the responders were apprehensive of providing treatment to patients suspected of being infected with COVID 19, even though 96\% of them thought proper hand washing and use of PPE have an effective role in preventing COVID -19. Study by Khanal et al. ${ }^{16}$ showed $20 \%$ of the participants have not been restricting aerosol generating procedures and have not been deferring non-emergency treatment during the time of COVID-19. This study showed $43 \%$ of the endodontists of Nepal have been deferring non-emergency procedures during the COVID pandemic. It was observed that the recently passed out endodontists with experience of less than five years reported better and significant knowledge scores as compared to graduates with more than five years of experience. There was no statistically significant difference among knowledge level of male and female responders. Endodontists practicing in Lumbini and Bagmati province have better knowledge on COVID -19 than their colleagues from other provinces of Nepal.

The study was conducted during the period when the spread of COVID-19 was increasing in Nepal and endodontists were stressed and struggling to acclimatize to disruptions in their social, economic, and professional life. For these reasons, the response rate was relatively low (83\%), and the possibility of response bias cannot be ruled out. Also, due to employed sampling technique and the cross-sectional nature of the study, self-selection bias on the side of the respondents cannot be ruled out.

\section{CONCLUSIONS}

Endodontists of Nepal are aware about the current scenario of COVID-19 and its etiology and preventive measures. The study showed that majority of endodontists have good knowledge and awareness regarding the global pandemic and the dentists are more susceptible for the transmission of diseases. Our findings have important implications for the development of strategies suitable for improving the level of practice among endodontists and enhance prevention programs. The implementation of special precautions can prevent disease spread from patients and serve as a guide for managing other respiratory diseases in the future.

\section{LIMITATIONS}

The major limitation was short time duration for data collection, which could have resulted in a smaller than expected sample as the information from WHO and national guidelines regarding the coronavirus and the pandemic was rapidly changing and it could affect the survey. The practice of endodontists recorded is just a subjective response reported by the practitioners themselves and it could be another limitation of the study. The administration and healthcare preventive measures implemented by provinces across the country were different, that could also influence the result of the study. Therefore, the findings of the current survey should be interpreted cautiously and should not be generalized.

CONFLICT OF INTEREST: None declared

\section{SORCE OF FUNDING: None}

\section{REFERENCES}

1. Li Q, Guan X, Wu P, Wang X, Zhou L, Tong Y, et al . Early transmission dynamics in Wuhan, China, of 
novel coronavirus-infected pneumonia. N Engl J Med. 2020;382(13):1199-207. DOI:10.1056/ NEJMoa2001316.

2. Zhu N, Zhang D, Wang W, Li X, Yang B, Song J,et al. A novel coronavirus from patients with pneumonia in China, 2019. N Engl J Med. 2020;382(8):727-33. DOI: 10.1056/NEJMoa2001017.

3. Sah MK, Singh A, Sangroula RK. Knowledge of novel coronavirus disease (COVID-19) among dental surgeons of Nepal: a nationwide study. BMC infectious diseases. 2020;20(1):1-7. DOI: 10.1186/s12879-02005620-4.

4. Gralinski LE, Menachery VD. Return of the Coronavirus: 2019-nCoV. Viruses. 2020 Jan 24;12(2):135. DOI: 10.3390/v12020135 PMID: 31991541.

5. Klompas M, Baker MA, Rhee C. Airborne transmission of SARS-CoV-2: theoretical considerations and available evidence. JAMA. 2020;324(5):441-442. DOI:10.1001/ jama.2020.12458 PMID: 32658248.

6. Chen N, Zhou M, Dong X, Qu J, Gong F, Han Y, et al. Epidemiological and clinical characteristics of 99 cases of 2019 novel coronavirus pneumonia in Wuhan, China: a descriptive study. Lancet. 2020;395(10223):507513. DOI:10.1016/S0140-6736(20)30211-7 PMID: 32007143.

7. Kamate SK, Sharma S, Thakar S, Srivastava D, Sengupta $\mathrm{K}$, Hadi AJ, et al. Assessing Knowledge, Attitudes and Practices of dental practitioners regarding the COVID-19 pandemic: A multinational study. Dent Med Probl. 2020;57(1):11-17. DOI:10.17219/ dmp/119743 PMID: 32307930.

8. Samaranayke LP, Peiris M. Severe acute respiratory syndrome and dentistry. A retrospective view. J Am Dent Assoc. 2004;135(9):1292-1302. DOI:10.14219/ jada.archive.2004.0405 PMID: 15493394.

9. Shrestha R, Shrestha S, Khanal P, Kc B. Nepal's first case of COVID-19 and public health response. J Travel Med. 2020;27(3):taaa024. DOI:10.1093/jtm/taaa024 PMID: 32104884.

10. KhaderY,Al Nsour M,Al-Batayneh OB,Saadeh R, Bashier $\mathrm{H}$, Alfaqih M, et al. Dentists' awareness, perception, and attitude regarding COVID-19 and infection control: cross-sectional study among Jordanian dentists. JMIR Public Health Surveill. 2020;6(2):e18798. DOI: 10.2196/18798 PMID: 32250959.
11. Kathree BA, Khan SB, Ahmed R, Maart R, Layloo $\mathrm{N}$, Asia-Michaels W. COVID-19 and its impact in the dental setting: A scoping review PLoS One. 2020;15(12):e0244352. DOI: 10.1371/journal. pone.0244352 PMID: 33338073.

12. Infection Control Guidance for Healthcare Professionals about Coronavirus (COVID-19) [Internet]. Atlanta: Centers for Disease Control and Prevention; Available from: https://www.cdc.gov/coronavirus/2019-ncov/ infection-control/control recommendations.html

13. Coronavirus frequently asked questions. Available from: https://success.ada.org/en/practicemanagement/patients/coronavirus-frequently-askedquestions.html [Accessed 14th December 2021]

14. Arora S, Abullais Saquib S, Attar N, Pimpale S, Saifullah Zafar K, Saluja P, et al. Evaluation of knowledge and preparedness among Indian dentists during the current COVID-19 pandemic: A Cross-sectional Study. J Multidiscip Healthc. 2020;13:841-854. DOI: 10.2147/ JMDH.S268891 PMID: 32922024.

15. Humagain M, Humagain R, Rokaya D. Dental Practice during COVID-19 in Nepal: A Descriptive Crosssectional Study. J Nepal Med Assoc [Internet]. 2020;58(230):764-9. DOI: 10.31729/jnma.5022.

16. Ahmed MA, Jouhar R, Ahmed N, Adnan S, Aftab $M$, Zafar MS, et al. Fear and Practice Modifications among Dentists to Combat Novel Coronavirus Disease (COVID-19) Outbreak. Int J Environ Res Public Health. 2020;17(8):2821. DOI: 10.3390/ijerph17082821 PMID: 32325888.

17. Tandon A, Ivatts S, Cowley P, Dodd R, Mikkel-Lopez I, Pepperall J, et al. Economic Contraction from COVID-19 in the Pacific: Implications for Health Financing. Health Syst Reform. 2020;6(1):e1847991. DOI: 10.1080/23288604.2020.1847991 PMID: 33337274.

18. Gebretsadik D, Gebremichael S, Belete MA. Knowledge, attitude and practice toward COVID-19 pandemic Among Population Visiting Dessie Health Center for COVID-19 Screening, Northeast Ethiopia. Infect Drug Resist. 2021;14:905-915. DOI: 10.2147/IDR.S297047 PMID: 33716509.

19. Khanal N, Singh AK. Knowledge, Attitude and Practice Regarding COVID-19 and Its Impact on Dentistry. A Cross-sectional Survey among Nepalese Dentists. Kathmandu Univ Med J. 2020; COVID-19 Special Issue 
70(2):3-9. DOI: 10.3126/kumj.v18i2.32937 PMID: 33605231 .

20. Khurshid Z, Asiri FYI, Al Wadaani H. Human Saliva: Non-Invasive Fluid for Detecting Novel Coronavirus (2019-nCoV). Int J Environ Res Public Health. 2020;17(7):2225. DOI:10.3390/ijerph17072225 PMID: 32224986.

21. Meng L, Hua F, Bian Z. Coronavirus Disease 2019 (COVID-19): Emerging and Future Challenges for Dental and Oral Medicine. J Dent Res. 2020;99(5):481-487. DOI:10.1177/0022034520914246 PMID: 32162995.
22. Modi PD, Nair G, Uppe A, Modi J, Tuppekar B, Gharpure AS, et al. COVID-19 Awareness Among Healthcare Students and Professionals in Mumbai Metropolitan Region: A Questionnaire-Based Survey. Cureus. 2020;12(4):e7514. DOI: 10.7759/cureus.7514. PMID: 32377462 .

23. Ahmed N, Shakoor M, Vohra F, Abduljabbar T, Mariam Q AbdulRehman M. Knowledge, Awareness and Practice of Health careProfessionals amid SARSCoV-2, Corona Virus Disease Outbreak. Pakistan J Med Sci. 2020;36(COVID19-S4). DOI:10.12669/pjms.36. covid19-s4.2704 PMID: 32582314. 